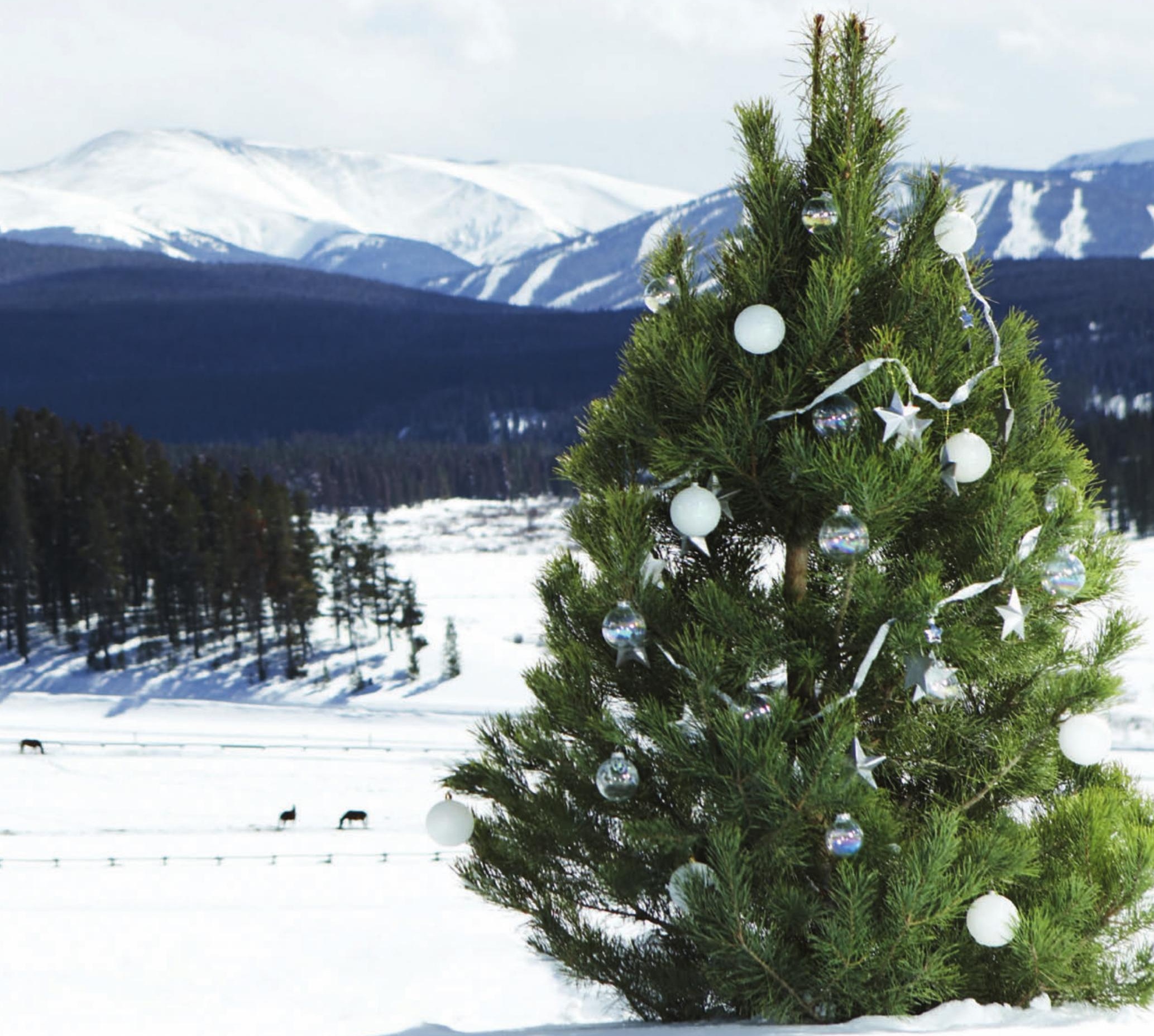

Frohe Festtage und ein glückliches neues Jahr!

Joyeuses fêtes et une excellente année 2017!

Buone feste ed un felice anno nuovo!

\section{GMH SERVICES}

FMMH Services Genossenschaft Burghöhe 1, 6208 Oberkirch Tel. 0419250077 - Fax 0419250067 mai@@fmhservices.ch - www.fmhservices.ch 